\title{
Geovibrio thiophilus sp. nov., a novel sulfur- reducing bacterium belonging to the phylum Deferribacteres
}

\footnotetext{
${ }^{1}$ Max-Planck-Institut für Terrestrische Mikrobiologie, D-35043 Marburg, Germany

2 Fakultät für Biologie, Universität Konstanz, D-78434 Konstanz, Germany
}

\author{
Peter H. Janssen, ${ }^{1}+$ Werner Liesack ${ }^{1}$ and Bernhard Schink ${ }^{2}$ \\ Author for correspondence: Peter H. Janssen. Tel: +6138344 5706. Fax: +61393471540. \\ e-mail:pjanssen@unimelb.edu.au
}

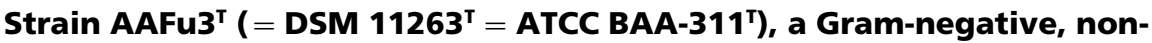
sporulating bacterium, was isolated from a methanogenic mixed culture growing with acetone, in which acetate was the major intermediate. The cells of strain AAFu3 ${ }^{\top}$ were slender spirilla, usually of less than one turn, and were motile by means of a single polar flagellum. The cells contained c-type cytochromes and the G+C content of the genomic DNA was $\mathbf{5 0 . 2} \mathrm{mol} \%$. Sulfur, nitrate, fumarate, DMSO and oxygen (microaerophilically) were used as electron acceptors, but sulfate, sulfite, thiosulfate and ferric iron were not. Sulfide, hydrogen, formate and acetate acted as electron donors for respiratory growth, while fumarate, maleate and L-malate supported fermentative growth. Neither fermentative nor respiratory growth was supported by carbohydrates, fatty acids more than two carbons long, alcohols or amino acids. The strain was a mesophile. Comparative sequence analysis of the 165 rRNA gene and comparison of phenotypic characteristics showed that strain AAFu $^{\top}$ is closely related to Geovibrio ferrireducens, within the phylum Deferribacteres. Strain AAFu3 ${ }^{\top}$ was designated as the type strain of a new species, for which the name Geovibrio thiophilus is proposed.
\end{abstract}

Keywords: Geovibrio thiophilus sp. nov., sulfur reduction, microaerophile, anaerobe
We have been studying a mixed culture of anaerobic micro-organisms that degrades acetone to methane and carbon dioxide (Platen \& Schink, 1987; Platen et al., 1994). The mixed culture consists of (1) a rodshaped bacterium that is postulated to convert acetone to acetate, (2) a methanogen, Methanosaeta concilii, that metabolizes the acetate produced by the rodshaped bacterium to methane and carbon dioxide, and (3) a slender, curved bacterium with no known role in the mixed culture. We isolated this third bacterium, which we have named strain $\mathrm{AAFu}^{\mathrm{T}}$, in pure culture and found that it could not metabolize acetone (Platen et al., 1994). To understand its possible role in the mixed culture, we characterized this strain in detail.

\footnotetext{
† Present address: Department of Microbiology and Immunology, University of Melbourne, Parkville, Victoria 3010, Australia.

The GenBank accession number for the $16 \mathrm{~S}$ rRNA sequence of strain AAFu3 $^{\top}$ is AJ299402.
}

\section{Growth}

Strain $\mathrm{AAFu}^{\mathrm{T}}$ was routinely grown in the sulfidereduced, bicarbonate-buffered, vitamin-supplemented medium FM (Janssen et al., 1997), at $30^{\circ} \mathrm{C}$. Screwcapped bottles were filled, leaving a small gas bubble, or serum bottles were partly filled [the headspace being gassed with $\mathrm{N}_{2}$ plus $\mathrm{CO}_{2}(80: 20, \mathrm{v} / \mathrm{v})$ ] and closed with butyl-rubber stoppers. Unless noted otherwise, the growth substrate was $10 \mathrm{mM}$ acetate plus $20 \mathrm{mM}$ fumarate. L-isomers of chiral organic and amino acids and D-isomers of sugars were used, unless noted otherwise. 2,3-Butanediol (Fluka) was a mix of racemic and meso forms. Substrates and other supplements were prepared as neutralized (with $\mathrm{NaOH}$ or $\mathrm{HCl}$ as required) $200 \mathrm{mM}$ to $2 \mathrm{M}$ stock solutions and sterilized by autoclaving or, in the case of heat-labile compounds and sugars, by sterile filtration $(0 \cdot 2 \mu \mathrm{m}$ pore size $)$. Substrates were added to sterile media just before inoculation. Elemental sulfur was prepared as an aqueous slurry (Janssen et al., 1997) and added at approximately $100 \mathrm{mmol} \mathrm{l}^{-1}$. Hydrogen was added to the $\mathrm{N}_{2} / \mathrm{CO}_{2}$ headspace of partially filled serum bottles 
to an overpressure of $0.6 \mathrm{bar}$. Oxygen was added to the $\mathrm{N}_{2} / \mathrm{CO}_{2}$ headspace of similar cultures to the desired final partial pressure, using $\mathrm{FM}$ without $\mathrm{Na}_{2} \mathrm{~S}$ and with $2 \mathrm{mM} \mathrm{Na}{ }_{2} \mathrm{~S}_{2} \mathrm{O}_{3}$ as a sulfur source. Nitrate, sulfate and thiosulfate were added as sodium salts. Amorphous ferric iron was prepared as described by Lovley \& Phillips (1986) and added from an autoclaved stock suspension at $30 \mathrm{mmol} \mathrm{Fe}$ (III) per litre FM with $2 \mathrm{mM}$ L-cysteine as the reducing agent (instead of $\mathrm{Na}_{2} \mathrm{~S}$ ) and with $2 \mathrm{mM} \mathrm{Na}_{2} \mathrm{SO}_{4}$ or $1 \mathrm{mM} \mathrm{Na} \mathrm{S}_{2} \mathrm{O}_{3}$ as an additional sulfur source.

Strain AAFu3 $3^{\mathrm{T}}$ grew most rapidly at 37 and $40{ }^{\circ} \mathrm{C}$. Growth was possible at $4{ }^{\circ} \mathrm{C}$, but not at $45^{\circ} \mathrm{C}$. All further experiments were incubated at $30^{\circ} \mathrm{C}$. Growth was not inhibited when the $\mathrm{NaCl}$ and $\mathrm{MgCl}_{2} \cdot 6 \mathrm{H}_{2} \mathrm{O}$ concentrations in the medium were increased from 1 and $0.4 \mathrm{~g} \mathrm{l}^{-1}$ to 20 and $3 \mathrm{~g} \mathrm{l}^{-1}$, respectively.

\section{General characteristics}

Cells of strain $A A F u 3^{T}$ were slender spirilla (Fig. 1a). The cells were $0.35 \mu \mathrm{m}$ in diameter, $2.5-6 \mu \mathrm{m}$ long and each had a single polar flagellum (Fig. 1b). The cells were motile, speeds of up to $50-60 \mu \mathrm{m} \mathrm{s}^{-1}$ being commonly observed under phase-contrast microscopy of wet mounts. Sporulation was tested by adding $1 \mathrm{ml}$ sterile soil extract (Cote \& Gherna, 1994) to $50 \mathrm{ml}$ medium supplemented with $0.5 \mathrm{~g}$ thiamin $1^{-1}, 0.5 \mathrm{~g}$ $\mathrm{CaCl}_{2} \cdot 2 \mathrm{H}_{2} \mathrm{Ol}^{-1}$ and $0 \cdot 3 \mathrm{~g} \mathrm{MnCl}_{2} \cdot 4 \mathrm{H}_{2} \mathrm{Ol}^{-1}$. No spores were observed by phase-contrast microscopy of cultures grown in this medium. The Gram stain (Süßmuth et al., 1987) reaction was negative. Colonies in agar deeps (Widdel \& Bak, 1992) were lens-shaped and red in colour. Difference spectra of crude cell-free extracts (Janssen et al., 1996b) of acetate + fumarategrown cells revealed the presence of $c$-type cytochromes, with absorption maxima of $424,523.5$ and $553.5 \mathrm{~nm}$. The $\mathrm{G}+\mathrm{C}$ content of the genomic DNA was $50 \cdot 2 \mathrm{~mol} \%(\mathrm{SD}=0 \cdot 3, n=3)$, determined by reversedphase HPLC (Janssen et al., 1996a). Tests for aesculin hydrolysis, indole production from L-tryptophan and urease activity (Janssen et al., 1997) were all negative.

\section{Metabolism}

Strain AAFu3 ${ }^{\mathrm{T}}$ grew fermentatively with fumarate, Lmalate and maleate (Table 1). The concentrations of growth substrates and organic end-products of metabolism were measured by ion-exclusion HPLC (Krumböck \& Conrad, 1991). Succinate was the sole organic end-product of catabolism of these substrates, $6 \mathrm{~mol}$ being produced from $7 \mathrm{~mol}$ substrate (Table 2). No acetate was formed. This indicated a complete oxidation of $1 \mathrm{~mol}$ substrate to $\mathrm{CO}_{2}$, the electrons arising from the oxidation being used to reduce fumarate to succinate. In the presence of sulfur, sulfide was formed with formate, acetate, hydrogen and D-malate, but not with L-malate, fumarate or maleate as electron donors. Sulfide production was measured colorimetrically (Cline, 1969). Formate and acetate were no longer
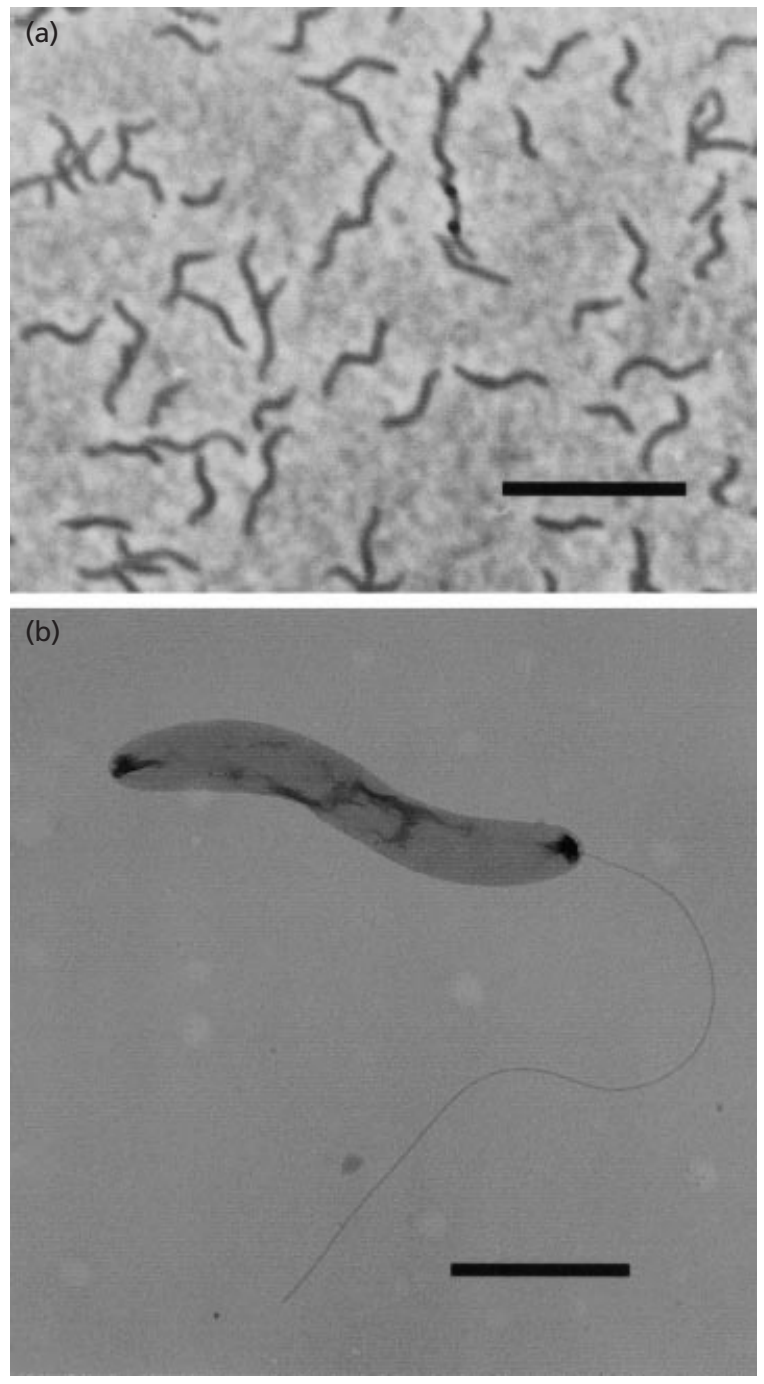

Fig. 1. Morphology of cells of strain $A A F u 3^{\top}$. (a) Living cells on an agar-coated slide (Pfennig \& Wagener, 1986) photographed using phase-contrast microscopy. Bar, $10 \mu \mathrm{m}$. (b) Electron micrograph (Chin et al., 2001) of a negatively stained cell, showing the polar flagellum. Bar, $1 \mu \mathrm{m}$.

detectable after growth and no organic catabolic products were detected, so these substrates were presumably oxidized to $\mathrm{CO}_{2}$. Succinate was formed from D-malate. Other organic acids, alcohols, sugars and amino acids did not support fermentative growth or sulfur reduction (Table 1). Sulfate $(20 \mathrm{mM})$, sulfite $(10 \mathrm{mM})$, thiosulfate $(20 \mathrm{mM})$, nitrite $(2$ or $10 \mathrm{mM})$ and amorphous ferric iron $(30 \mathrm{mM})$ were not used as electron acceptors with acetate as the electron donor. Fumarate, L-malate and formate were also tested as potential electron donors, with ferric iron as the potential electron acceptor, but iron was not reduced, although growth occurred in the cultures containing fumarate and L-malate. This indicated that ferric iron was not inhibitory and that growth could occur in the medium used for these experiments. The addition of 
Table 1. Substrates supporting growth of, and sulfur reduction by, strain AAFu3 ${ }^{\top}$

Initial concentrations, in $\mathrm{mM}$, are given in parentheses after each compound. Unless noted otherwise, L-isomers of organic and amino acids and D-isomers of sugars were tested. +, Growth or sulfide production observed; - , no growth or sulfide production observed. Compounds not used: glucose (4), cellobiose (2), fructose (4), L-rhamnose (4), xylose (4), galactose (4), lactose (2), mannose (4), maltose (2), ribose (4), sucrose (2), arabinose (4), melibiose (2), succinate (20), lactate (20), citrate (20), DL-3-hydroxybutyrate (20), crotonate (20), tartrate (20), pyruvate (20), acetone (10), methanol (20), ethanol (20), propanol (10), butanol (10), pentanol (5), ethylene glycol (20), glycerol (20), acetoin (20), mannitol (20), 2,3-butanediol (20), alanine (20), glutamate (20), glycine (20), threonine (20), lysine (20), aspartate (20), valine (20) and leucine (20). Propionate (10), butyrate (5), valerate (5), caprate (2), palmitate (1) and stearate (1) were tested only in the presence of sulfur.

\begin{tabular}{|lccc|}
\hline Compound used & Fermentative growth & Growth in the presence of sulfur & Sulfur reduction \\
\hline Fumarate (20) & + & + & - \\
Maleate (20) & + & + & - \\
L-Malate (20) & + & + & - \\
D-Malate (20) & - & - & + \\
Hydrogen* & - & + & + \\
Formate (20) & - & + & + \\
Acetate (10) & - & + & + \\
\hline
\end{tabular}

* Added at 0.6 bar in the headspace $(70 \mathrm{ml})$ over a liquid culture $(50 \mathrm{ml})$.

Table 2. Comparison of the utilization of growth substrates and electron acceptors with the products formed by strain AAFu3 ${ }^{\top}$

NQ, Not quantified.

\begin{tabular}{|c|c|c|c|c|c|}
\hline Substrate & $\begin{array}{l}\text { Amount utilized } \\
\left(\mathrm{mmol} \mathrm{l}^{-1}\right)\end{array}$ & Acceptor & $\begin{array}{l}\text { Amount utilized } \\
\left(\mathrm{mmol} \mathrm{l}^{-1}\right)\end{array}$ & Product & $\begin{array}{l}\text { Amount formed } \\
\left(\mathrm{mmol} \mathrm{l}^{-1}\right)\end{array}$ \\
\hline Fumarate & $13 \cdot 70$ & None & & Succinate & $10 \cdot 66$ \\
\hline Acetate & $5 \cdot 61$ & Fumarate & $19 \cdot 08$ & Succinate & $19 \cdot 13$ \\
\hline Acetate & $2 \cdot 32$ & Sulfur & NQ & Sulfide & $10 \cdot 23$ \\
\hline Acetate & $3 \cdot 68$ & DMSO & NQ & Dimethylsulfide & $13 \cdot 06$ \\
\hline Acetate & $12 \cdot 94$ & Nitrate & NQ & Ammonium & $7 \cdot 22$ \\
\hline Hydrogen & $10 \cdot 91$ & Sulfur & NQ & Sulfide & $10 \cdot 14$ \\
\hline Formate & $2 \cdot 21$ & Sulfur & NQ & Sulfide & $2 \cdot 54$ \\
\hline \multirow[t]{3}{*}{ Sulfide } & $2 \cdot 66$ & Nitrate & NQ & Sulfur & $2 \cdot 02$ \\
\hline & & & & Nitrite & $2 \cdot 13$ \\
\hline & & & & Ammonium & $0 \cdot 36$ \\
\hline
\end{tabular}

$2 \mathrm{mM}$ nitrilotriacetic acid or $20 \mathrm{mM}$ citric acid as a chelating agent (each from a stock solution that had been adjusted to $\mathrm{pH} 8 \cdot 0$ with $\mathrm{NaOH}$ ) did not facilitate the utilization of ferric iron as an electron acceptor, even after 3 months incubation. Sulfate and thiosulfate were added individually as sulfur sources in the presence of L-cysteine in the experiments testing the use of ferric iron as the potential electron acceptor, in case the inability to grow with ferric iron was really due to the lack of a suitable sulfur source in the absence of sulfide, but these additions did not result in growth with ferric iron. Sulfide was not formed from L- cysteine. Acetate was oxidized with fumarate $(20 \mathrm{mM})$, with nitrate $(20 \mathrm{mM})$ or with DMSO $(20 \mathrm{mM})$ as the electron acceptor (Table 2). Fumarate was reduced to succinate, nitrate to nitrite and ammonium, and DMSO to dimethylsulfide (Table 2). Colorimetric assays were used to measure the concentrations of ammonia (Chaney \& Marbach, 1962) and nitrite (Drews, 1983). Dimethylsulfide production was measured by GC (Kappler et al., 1997). Cultures growing with hydrogen and sulfur with no added organic compounds other than the vitamins in the medium could be repeatedly transferred, although growth was 


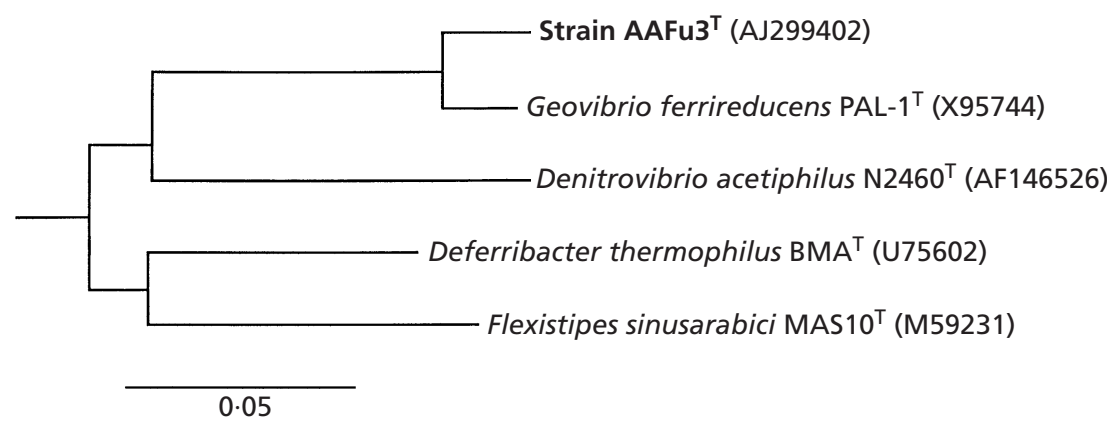

Fig. 2. $16 \mathrm{~S}$ rRNA gene-based distance dendrogram showing the phylogenetic position of strain $\mathrm{AAFu}^{\top}$ in relation to currently recognized members of the phylum Deferribacteres. Evolutionary distances were calculated using the Jukes-Cantor correction (Jukes \& Cantor, 1969) and 1324 alignment positions which contained identical nucleotides in at least $50 \%$ of the $16 \mathrm{~S}$ rRNA gene sequences were compared (Friedrich et al., 1996; Finster et al., 1998). The dendrogram was constructed from the resulting distance matrix using the neighbour-joining technique (Saitou \& Nei, 1987). The membership of all five organisms in this lineage was confirmed in all neighbour-joining treeing analyses (1000 data resamplings) with bootstrap values $>95 \%$ (data not shown). The root was determined in relation to a set of outgroup bacterial reference sequences (not shown). The GenBank accession numbers are shown in parentheses. Scale bar, 0.05 changes per nucleotide position. slower than when $2 \mathrm{mM}$ acetate was added. This suggested that strain $\mathrm{AAFu}^{\mathrm{T}}$ may be able to grow autotrophically, but the capacity for $\mathrm{CO}_{2}$ fixation was not investigated.

Strain AAFu $3^{\mathrm{T}}$ could not grow with acetate under a gas headspace containing 2 or $20 \%$ oxygen. No colonies developed in the upper $20 \mathrm{~mm}$ of agar deep cultures growing with acetate plus fumarate under a headspace of $\mathrm{N}_{2} / \mathrm{CO}_{2} / \mathrm{O}_{2}(3: 1: 1$, by vol.). Cultures were also grown in opposing gradients of oxygen and sulfide prepared by using a modification of the method of Nelson \& Jannasch (1983). These ' gradient cultures' were prepared in test tubes $(150 \times 18 \mathrm{~mm})$, capped with Kim-Kap polypropylene closures (KimbleKontes). Three millilitres of anoxic 3\% (w/v) agar containing a potential growth substrate were overlaid with $10 \mathrm{ml}$ anoxic FM without sulfide containing $0.3 \%$ agar and inoculated with $0.1 \mathrm{ml}$ well-grown culture. When sulfide was the growth substrate being tested, $10 \mathrm{mM} \mathrm{Na} 2 \mathrm{~S}$ neutralized with $13 \mathrm{mM} \mathrm{HCl}$ was added to the lower agar layer. A bacterial plate less than $0.3 \mathrm{~mm}$ thick formed about $3 \mathrm{~mm}$ under the surface of the upper agar layer in these cultures. The plate consisted of highly motile spiral-shaped cells and refractile globules that were presumably sulfur. No such plate formed in uninoculated tubes or in tubes incubated under a headspace of $\mathrm{N}_{2} / \mathrm{CO}_{2}(4: 1, \mathrm{v} / \mathrm{v})$. This suggested that strain AAFu $3^{\mathrm{T}}$ can oxidize sulfide under micro-oxic conditions, gaining energy from the chemolithotrophic oxidation of the reduced sulfur species. Growth in sulfide and oxygen gradients occurred in the absence of added acetate, providing additional evidence that autotrophic growth may be possible. No growth occurred in opposing gradients of oxygen and other substrates $[10 \mathrm{mM}$ acetate, $20 \mathrm{mM}$ formate $( \pm 1 \mathrm{mM}$ acetate in the upper agar layer), $20 \mathrm{mM}$ fumarate, $20 \mathrm{mM}$ L-malate or $20 \mathrm{mM}$ maleate], with either $2 \mathrm{mM} \mathrm{Na}_{2} \mathrm{SO}_{4}$ or $1 \mathrm{mM} \mathrm{Na}_{2} \mathrm{~S}_{2} \mathrm{O}_{3}$ as the potential sulfur source. It is possible that strain AAFu $3^{\mathrm{T}}$ could not grow with organic substrates in these experiments because sulfide was required as a sulfur source or to reduce the oxygen partial pressure. The oxygen partial pressures allowing growth have not been determined, nor have all of the potential endproducts of sulfide oxidation been assayed. Cultures were able to oxidize sulfide to sulfur, which was measured spectrophotometrically in benzene extracts of cell suspensions (Javor et al., 1990), when nitrate was added to the growth medium (Table 2).

Strain AAFu $3^{\mathrm{T}}$ has a very versatile metabolic repertoire, even though the range of energy sources it can use is relatively small. In the presence of sulfur or other electron acceptors, a range of products of fermentation can be oxidized in growth-supporting reactions. Growth is also possible under micro-oxic conditions. This suggests that the natural habitat of strain $\mathrm{AAFu} 3^{\mathrm{T}}$ is near the oxic/anoxic interface of freshwater sediments. The rapid motility displayed by the strain could enable the bacterium to position itself within gradients of oxygen and sulfide, or to move towards areas with favourable substrates. The persistence of strain $\mathrm{AAFu} 3^{\mathrm{T}}$ within the enrichment culture from which it was isolated is explained by its flexible metabolism: it can use acetate, the major intermediate in the mixed culture (Platen et al., 1994), and either oxygen, which diffuses even through butyl-rubber stoppers during the long incubation times required for cultivation of the mixed culture, or sulfur, which may be formed by the chemical oxidation of the sulfide reductant used in the growth medium. The strain may not have been involved in a direct metabolic or nutritional association with the other organisms present in the acetonedegrading consortium, comprising $M$. concilii and an unidentified bacterium (Platen \& Schink, 1987; Platen 
Table 3. Characteristics of strain $A A F u 3^{\top}$ and $G$. ferrireducens

Data on G. ferrireducens are from Caccavo et al. (1996). +, Characteristic present; -, characteristic absent; NR, not reported.

\begin{tabular}{|lcc|}
\hline Characteristic & Strain AAFu3 & G. ferrireducens \\
\hline Cell shape & Spiral & Spiral \\
Flagella & Single polar & Single polar \\
G+C content of genomic DNA $(\mathrm{mol} \%)$ & 50 & 43 \\
Cytochromes & $c$-type & $c$-type \\
Electron acceptors used & & + \\
Ferric iron & - & + \\
Sulfur & + & - \\
Nitrate & + & - \\
Sulfate, sulfite, thiosulfate & - & NR \\
Oxygen (microaerophilic) & + & - \\
Oxygen $(20 \%$ in air) & - & + \\
Electron donors used & & + \\
Acetate & + & + \\
Propionate & - & + \\
Hydrogen & + & + \\
Formate & + & + \\
Lactate & - & + \\
Pyruvate & - & NR \\
Succinate & - & - \\
Proline & - & + \\
Sulfide & + & + \\
Fermentative growth & + & + \\
\hline
\end{tabular}

et al., 1994), in the original sediment system from which the culture was derived. The degree of spatial heterogeneity over small distances in freshwater sediments (Brune et al., 2000) means that a sample of a surface sediment will encompass many different habitats. We conclude that strain $\mathrm{AAFu} 3^{\mathrm{T}}$ is probably not directly involved in acetone metabolism by the consortium. Nevertheless, it may still contribute to the stability of the mixed culture, perhaps by providing essential growth factors for the other members, or by scavenging oxygen that diffuses through the butylrubber stoppers, thus protecting the strictly anaerobic $M$. concilii and perhaps also the unidentified acetonecatabolizing bacterium.

\section{Phylogenetic analysis}

The almost complete sequence of the 16S rRNA gene of strain AAFu3 $3^{\mathrm{T}}$ was determined, as described by Finster et al. (1998). The gene sequence was added to a database of about 7200 bacterial 16S rRNA gene sequences with at least 1300 unambiguously determined nucleotide sequence positions, using the automatic alignment tool of the ARB program package and manual editing of the resulting alignment. This database is part of the ARB program package [version 2.5b, developed by O. Strunk and W. Ludwig, Technische Universität München (http://www.arb-home.de)].
The initial analysis clearly showed that strain AAFu3 ${ }^{\mathrm{T}}$ was phylogenetically affiliated with members of the phylum Deferribacteres (Garrity \& Holt, 2001). Phylogenetic placement of strain $\mathrm{AAFu} 3^{\mathrm{T}}$ was carried out in relation to the currently recognized members of the phylum Deferribacteres (Garrity \& Holt, 2001) and a set of reference sequences representative of other main lines of bacterial descent. The phylum Deferribacteres, equivalent to the division Flexistipes of Hugenholtz et al. (1998), is characterized by only four described genera and species (Fig. 2). These are Geovibrio ferrireducens (Caccavo et al., 1996), Flexistipes sinusarabici (Fiala et al., 1990), Deferribacter thermophilus (Greene et al., 1997) and Denitrovibrio acetiphilus (Myhr \& Torsvik, 2000). Strain AAFu3 ${ }^{\mathrm{T}}$ is most closely related to $G$. ferrireducens strain PAL- $1^{\mathrm{T}}$ (Fig. 2 ). The two strains share an overall similarity in their 16S rRNA gene sequences of $96.5 \%$, while the corresponding values to $F$. sinusarabici strain $\mathrm{MAS} 10^{\mathrm{T}}$, Deferribacter thermophilus strain $\mathrm{BMA}^{\mathrm{T}}$ and Denitrovibrio acetiphilus strain $\mathrm{N} 2460^{\mathrm{T}}$ are clearly lower, i.e. $84 \cdot 4,85 \cdot 6$ and $85 \cdot 0 \%$, respectively.

The metabolic capabilities of strain $\mathrm{AAFu} 3^{\mathrm{T}}$ increase the already wide range of metabolisms found in the few members of the phylum Deferribacteres that have been studied to date. Strain AAFu $3^{\mathrm{T}}$ displays phenotypic characteristics that differentiate it from G. ferrireducens (Table 3). The most significant of these is the 
apparent inability to reduce ferric iron, which is a key characteristic of G. ferrireducens (Caccavo et al., 1996). However, the similarity of the $16 \mathrm{~S}$ rRNA gene sequences and the similarities in morphology and general mode of metabolism suggest that $\mathrm{AAFu}^{\mathrm{T}}$ and $G$. ferrireducens are closely related. We propose that strain $\mathrm{AAFu} 3^{\mathrm{T}}$ be designated the type strain of a new species within the genus Geovibrio, for which the name Geovibrio thiophilus sp. nov. is proposed. The description is based on the type and only strain available at present.

\section{Description of Geovibrio thiophilus sp. nov.}

Geovibrio thiophilus (thi.o' phi.lus. Gr. n. theion sulfur; Gr. adj. philos loving; M.L. masc. adj. thiophilus sulfur-loving).

Gram-negative, spiral-shaped cells, $0 \cdot 35 \mu \mathrm{m}$ in diameter and 2.5-6 $\mu \mathrm{m}$ long, each motile by means of a single polar flagellum. Spores are not formed. Cells occur singly. Cells contain $c$-type cytochromes. The $\mathrm{G}+\mathrm{C}$ content of the genomic DNA is $50 \cdot 2 \mathrm{~mol} \%$. Uses sulfur, nitrate, fumarate, DMSO and oxygen (microaerophilically) as electron acceptors. Sulfide, hydrogen, formate and acetate act as electron donors for respiratory growth. Sulfate, sulfite, thiosulfate, nitrite and ferric iron are not used as electron acceptors. Fumarate, maleate and L-malate support fermentative growth. Neither fermentative nor respiratory growth is observed with carbohydrates, fatty acids more than two carbons long, acetone, alcohols or amino acids. Grows best in a growth medium with less than $20 \mathrm{~g} \mathrm{NaCl}^{-1}$. Grows most rapidly at $37-40{ }^{\circ} \mathrm{C}$. Growth is possible at $4{ }^{\circ} \mathrm{C}$, but not at $45^{\circ} \mathrm{C}$. Sequence analysis of the 16S rRNA gene shows that the species is closely related to Geovibrio ferrireducens. The type strain, AAFu3 ${ }^{\mathrm{T}}$, was isolated from the surface sediments of a ditch in Konstanz, Germany, and has been deposited in the DSMZ as DSM $11263^{\mathrm{T}}$ and in the American Type Culture Collection as ATCC BAA$311^{\mathrm{T}}$.

\section{Acknowledgements}

We thank Oliver Kappler for carrying out the dimethylsulfide analyses, and Sarah Wilson for help with the electron microscopy.

\section{References}

Brune, A., Frenzel, P. \& Cypionka, H. (2000). Life at the oxic-anoxic interface: microbial activities and adaptations. FEMS Microbiol Rev 24, 691-710.

Caccavo, F., Coates, J. D., Rossello-Mora, R. A., Ludwig, W., Schleifer, K. H., Lovley, D. R. \& McInerney, M. J. (1996). Geovibrio ferrireducens, a phylogenetically distinct dissimilatory $\mathrm{Fe}(\mathrm{III})$-reducing bacterium. Arch Microbiol 165, 370-376.

Chaney, A. L. \& Marbach, E. P. (1962). Modified reagents for determination of urea and ammonia. Clin Chem 8, 130-132.

Chin, K. J., Liesack, W. \& Janssen, P. H. (2001). Description of Opitutus terrae gen. nov., sp. nov., to accommodate new strains of the division Verrucomicrobia isolated from rice paddy soil. Int J Syst Evol Microbiol 51, 1965-1968.

Cline, J. D. (1969). Spectrophotometric determination of hydrogen sulfide in natural waters. Limnol Oceanogr 14, 454-458.

Cote, R. J. \& Gherna, R. L. (1994). Nutrition and media. In Methods for General and Molecular Microbiology, pp. 155-178. Edited by P. Gerhardt, R. G. E. Murray, W. A. Wood \& N. R. Krieg. Washington, DC: American Society for Microbiology.

Drews, G. (1983). Mikrobiologisches Praktikum, 4th edn. Berlin: Springer.

Fiala, G., Woese, C. R., Langworthy, T. A. \& Stetter, K. O. (1990). Flexistipes sinusarabici, a novel genus and species of eubacteria occurring in the Atlantis II Deep brines of the Red Sea. Arch Microbiol 154, 120-126.

Finster, K., Liesack, W. \& Thamdrup, B. (1998). Elemental sulfur and thiosulfate disproportionation by Desulfocapsa sulfoexigens sp. nov., a new anaerobic bacterium isolated from marine surface sediment. Appl Environ Microbiol 64, 119-125.

Friedrich, M., Springer, N., Ludwig, W. \& Schink, B. (1996). Phylogenetic positions of Desulfofustis glycolicus gen. nov., sp. nov., and Syntrophobotulus glycolicus gen. nov., sp. nov., two new strict anaerobes growing with glycolic acid. Int J Syst Bacteriol 46, 1065-1069.

Garrity, G. M. \& Holt, J. G. (2001). Phylum BIX. Deferribacteres phy. nov. In Bergey's Manual of Systematic Bacteriology, 2nd edn, vol. 1, pp. 465-471. Edited by D. R. Boone \& R. W. Castenholz. New York: Springer.

Greene, A. C., Patel, B. K. C. \& Sheehy, A. J. (1997). Deferribacter thermophilus gen. nov., sp. nov., a novel thermophilic manganese- and iron-reducing bacterium isolated from a petroleum reservoir. Int $J$ Syst Bacteriol 47, 505-509.

Hugenholtz, P., Goebel, B. M. \& Pace, N. R. (1998). Impact of culture-independent studies on the emerging phylogenetic view of bacterial diversity. J Bacteriol 180, 4765-4774.

Janssen, P. H., Liesack, W., Kluge, C., Seeliger, S., Schink, B. \& Harfoot, C. G. (1996a). Sodium-dependent succinate decarboxylation by a new anaerobic bacterium belonging to the genus Peptostreptococcus. Antonie Leeuwenhoek 70, 11-20.

Janssen, P. H., Schuhmann, A., Bak, F. \& Liesack, W. (1996b). Disproportionation of inorganic sulfur compounds by the sulfatereducing bacterium Desulfocapsa thiozymogenes gen. nov., sp. nov. Arch Microbiol 166, 184-192.

Janssen, P. H., Schuhmann, A., Mörschel, E. \& Rainey, F. A. (1997). Novel anaerobic ultramicrobacteria belonging to the Verrucomicrobiales lineage of bacterial descent isolated by dilution culture from anoxic rice paddy soil. Appl Environ Microbiol 63, 1382-1388.

Javor, B. J., Wilmot, D. B. \& Vetter, R. D. (1990). pH-Dependent metabolism of thiosulfate and sulfur globules in the chemolithotrophic marine bacterium Thiomicrospira crunogena. Arch Microbiol 154, 231-238.

Jukes, T. H. \& Cantor, C. R. (1969). Evolution of protein molecules. In Mammalian Protein Metabolism, vol. 3, pp. 21-132. Edited by H. N. Munro. New York: Academic Press.

Kappler, O., Janssen, P. H., Kreft, J. U. \& Schink, B. (1997). Effects of alternative methyl group acceptors on the growth energetics of the $O$ demethylating anaerobe Holophaga foetida. Microbiology 143, 11051114 .

Krumböck, M. \& Conrad, R. (1991). Metabolism of position-labeled glucose in anoxic methanogenic paddy soil and lake sediment. FEMS Microbiol Ecol 85, 247-256.

Lovley, D. R. \& Phillips, E. J. P. (1986). Organic matter mineralization with reduction of ferric iron in anaerobic sediments. Appl Environ Microbiol 51, 683-689.

Myhr, S. \& Torsvik, T. (2000). Denitrovibrio acetiphilus, a novel genus and species of dissimilatory nitrate-reducing bacterium isolated from an oil reservoir model column. Int J Syst Evol Microbiol 50, 1611-1619.

Nelson, D. C. \& Jannasch, H. W. (1983). Chemoautotrophic growth of a marine Beggiatoa in sulfide-gradient cultures. Arch Microbiol 136, 262-269. 
Pfennig, N. \& Wagener, S. (1986). An improved method of preparing wet mounts for photomicrographs of microorganisms. J Microbiol Methods 4, 303-306.

Platen, H. \& Schink, B. (1987). Methanogenic degradation of acetone by an enrichment culture. Arch Microbiol 149, 136-141.

Platen, H., Janssen, P. H. \& Schink, B. (1994). Fermentative degradation of acetone by an enrichment culture in membrane-separated culture devices and in cell suspensions. FEMS Microbiol Lett 122, $27-32$.
Saitou, N. \& Nei, M. (1987). The neighbor-joining method: a new method for reconstructing phylogenetic trees. Mol Biol Evol 4, 406-425. Süßmuth, R., Eberspächer, J., Haag, R. \& Springer, W. (1987). Biochemisch-mikrobiologisches Praktikum. Stuttgart: Thieme.

Widdel, F. \& Bak, F. (1992). Gram-negative mesophilic sulfatereducing bacteria. In The Prokaryotes. A Handbook on the Biology of Bacteria. Ecophysiology, Isolation, Identification, Applications, 2nd edn, pp. 3352-3378. Edited by A. Balows, H. G. Trüper, M. Dworkin, W. Harder \& K.-H. Schleifer. New York: Springer. 